Ann E. Barry RN PHN, Michael A. Noble MD FRCP(C), Thomas J. Marrie MD FRCP(C), Isobel J, Paterson RN PHN

\title{
Cleaning of anaesthesia breathing circuits and tubings: a Canadian survey
}

A cross-Canada survey of 38 university-affilated hospiwals with over 250 beds was undertaken to examine the procedures for cleaning anaesthetic tubings and circuits. Twenty-eight (74 per cent) hospitals responded. Gluteraldehyde was the mosi commonly used method $13 / 28$, and pasteurization was the second most used method (9i28). These wo methods are described and recommendations are made for basic requirements for disinfection.

Key words

EQUIPMENT: disinfection, sterilization.

A literature search of practices for cleaning anaes thetic equipment demonstrated that differences exist in the method of decontaminating anaesthetic tubing and circuits. There is also controversy as to whether or not anaesthesia equipment is responsible for postoperative respiratory infection.

The only published guidclines we found were those of the American Operating Room Nurses? Association' which recommend that the entire anaesthetic equipment system, including breathing tubes, be terminally decontaminated, cleaned and sterilized after each use.

To identify the different cleaning methods used in Canadian hospitals, we did a cross-Canada survey in the spring of 1982 on cleaning practices in 38 university-affiliated hospitals.

From the Department of Medicine, Dalhousie University, Halifax, Nova Scotia and Departments of Microbiology and Infection Control, Victoria Gencral Hospital, Halifax, Nova Scotia

Address correspondence to: Ann $\mathrm{E}$. Barry, Infection Control Nurse, Infection Control Department, Victoria General Hospita), Halifax, Nova Scotia, Canada B3H $2 Y 9$.

\section{Methods}

The survey report was in the form of a questionnaire designed to allow respondents to mark any or all of the choices provided, with space allowed for additional comments.

The questionnaire asked about methods of cleaning circuits between patients, disinfectants used, the storage of cleaned circuits, water source and treatment, and number of tubing circuits per surgical suite.

Each questionnaire, along with a self-addressed, stamped envelope, was sent to the Chief Anaesthesia Technician of 38 hospitals. To ensure input Canada-wide, the centres were chosen on the basis of their geographical location, size and teaching affiliation. Twenty-eight responses were received. No attempt was made to contact the remaining hospitals. However, all twenty-eight participants were contacted by telephone one year later to verify replies and to asccrtain whether any changes had occurred. The number of revisions reported was minimal but did include two major alterations both within the province of Quebec. One hospital reported transferring the locale for cleaning from the operating room to the respiratory department while the other indicated a shift from chemical disinfection with proviodine to pasteurization

In hospitals that used pasteurization, specific questions were asked to determine whether there had been any equipment deterioration. No destruction was reported from those presently using this system.

\section{Results}

Overall results for Canada are seen in the Table. The majority ( 54 per cent) of hospitals had their equipment cleaned in the operating room by anaesthetic personnel. Twenty-one and 25 per cent respectively used the services of the sterile supply 
TABLE Survey results

\begin{tabular}{|c|c|c|c|c|c|c|}
\hline Factor & $\begin{array}{l}\text { B.C. } \\
(5)^{*}\end{array}$ & $\begin{array}{l}\text { Prairies } \\
(7)\end{array}$ & $\begin{array}{l}\text { Ont } \\
(9)\end{array}$ & $\begin{array}{l}P . Q \\
\text { (3) }\end{array}$ & $\begin{array}{l}\text { Maritimes } \\
\text { (4) }\end{array}$ & $\begin{array}{l}\text { Total } \\
(28)\end{array}$ \\
\hline \multicolumn{7}{|l|}{ Cleaning location } \\
\hline Sterile supply services & 0 & 0 & 3 & 0 & 3 & 6 \\
\hline Operating room & 3 & 5 & 4 & 2 & 1 & 15 \\
\hline Respiratory dept. & 2 & 2 & 2 & 1 & 0 & 7 \\
\hline \multicolumn{7}{|l|}{ Method of cleaning } \\
\hline Green soap & 0 & 0 & 1 & 0 & 1 & 2 \\
\hline Glutaraldehyde & 1 & 6 & 2 & 1 & 3 & 13 \\
\hline Pasteurization & 4 & 1 & 2 & 2 & 0 & 9 \\
\hline Other ${ }^{\dagger}$ & 0 & 0 & 4 & 0 & 0 & 4 \\
\hline \multicolumn{7}{|l|}{ Storage } \\
\hline Hang dry & 5 & 6 & 6 & 2 & 3 & 22 \\
\hline Hang bagged & 0 & 0 & 0 & ] & 1 & 2 \\
\hline Other & 0 & 1 & 3 & 0 & 0 & 4 \\
\hline \multicolumn{7}{|l|}{ Type of water used } \\
\hline Tap & 5 & 6 & 9 & 3 & 4 & 27 \\
\hline Stcrile/distilled & 0 & 1 & 0 & 0 & 0 & 1 \\
\hline \multicolumn{7}{|c|}{$\begin{array}{l}\text { Number of sets of } \\
\text { equipment/operating theatre } \neq\end{array}$} \\
\hline 1 & l & 0 & 0 & 1 & 1 & 3 \\
\hline 2 & 0 & 0 & 2 & 0 & 0 & 2 \\
\hline 3 & 1 & 1 & 1 & 0 & 0 & 3 \\
\hline$>3$ & 3 & 5 & 4 & 2 & 1 & 15 \\
\hline
\end{tabular}

* Number of hospitals responding.

$\dagger A$ variety of disinfectants including Wescodyne ${ }^{R}$, SurgiKleen ${ }^{R}$ and Chlorthexidine in $70 \%$ alcohbl.

$\ddagger$ Not reported by all centres.

department or the respiratory department. Forty-six per cent indicated the use of a glutaraldehycle disinfectant. Tap water was reported by 96 per cent of the hospitals as the medium of choice for rinsing after which 79 per cent hung tubings dry and unbagged.

Of the remaining centres, 32 per cent used pasteurization for disinfection, seven per cent employed green soap while the 14 per cent remaining reported a variety of disinfectants which included Chlorhexidine in 70 per cent alcohol, Wescodyne $^{\mathrm{R}}$ and steam, and SurgiKleen. ${ }^{\mathrm{R}}$ After completion of the cleaning process 79 per cent of hospitals indicated hanging tubings dry while seven per cent reported hanging tubing in bags. The other 14 per cent noted other methods of storage, including storing on flat surfaces in bags. Only 23 centres responded with the number of tubings available per suite. However, 78 per cent of them indicated at least three sets of tubing for each operating room suite. Thirteen per cent reported only one set per room. The remaining nine per cent noted the provision of two sets.

Regional disparity was most noticeable in the reported mode of cleaning. One hospital in the Maritimes reported prior use of pasteurization equipment but experienced deterioration of circuits and tubings and therefore discontinued this practice. (No other users had similar problems.)

\section{Discussion}

Controversy exists as to whether contaminated anaesthesia equipment is responsible for postoperative respiratory infections. Du Moulin et al ${ }^{2,3}$ and Stark et al. ${ }^{4}$ question this cause-effect relationship. However, most authors ${ }^{5-10}$ support the association between anaesthetic equipment and cross-colonization and describe cases where cross-infection have 
occurred as a result of inadequately cleaned equipment.

What is now of issue is to what extent equipment needs to be cleaned, and also to what limits one needs to go to prevent cross-colonization.

It has been reported that bacterial spores do not represent an infection hazard ${ }^{5,11}$ and studies by du Moulin and Saubermann, ${ }^{2}$ and Feeley ${ }^{12}$ suggest sterile equipment is not necessary. However, it does seem logical that disinfecting the breathing circuits is necessary,

Forty-seven per cent of the hospitals we surveyed disinfected with a glutaraldehyde. A two per cent solution kills bacteria and viruses within 10 to 20 minutes, although ten hours of soaking are required to kill spores. ${ }^{13}$ In addition to the 10 - to 20 -minute time advantage, glutaraldehyde disinfection is inexpensive and effective. However, use of this method requires gloves to protect hands of workers and a well-ventilated area to allow escape of irritant fumes. Thorough rinsing of equipment is necessary to prevent irritation of tissues. ${ }^{14}$

From our sample, pasteurization is the second most popular method used by 32 per cent of hospitals. Pasteurization involves the use of an automatic washing machine supplied with water at $77^{\circ} \mathrm{C}\left(170^{\circ} \mathrm{F}\right)$. Dirty equipment is placed in the tub and goes through a ten-minute wash cycle followed by a five-minute rinse cycle. Due to filling and emptying, the total exposure time is approximately 20 minutes allowing a fairly rapid turn-over of equipment. After the initial financial outlay, the procedure is relatively inexpensive. ${ }^{14}$ It is an effective means of disinfection, killing classical bacteria with ease ${ }^{15}$ without apparently harming plastic. However, Gurevich has described a failure rate of 83 per cent in disinfecting tubing, seeded with Pseudomonas aeruginosa and Acinetobacter by pasteurization ( $10^{7}$ colony forming units). Failure rate with glutaraldehyde disinfection in the same study was only six per cent. ${ }^{16}$ The results of this study may not necessarily be valid because of the extremcly large numbers of organisms used in the seeded tubes.

An alternative to disinfecting multi-use tubings and circuits is to use disposable single-use equipment. However, the cost of this convenience makes it a prohibitive method in most centres. In a 1982 comparison study, Wasse and Curtis ${ }^{14}$ of Seattle, Washington, projected a yearly cost of $\$ 30,692.75$ for disposable circuits based on the use of 40 circuits per day. Using the same daily quota, reuseable circuits disinfected with a glutaraldehyde in a Cidematic ${ }^{\top \mathrm{s}}$ machine would cost $\$ 7,143.80$ while the Pasteurmatic ${ }^{\text {Th }}$ cycle was estimated at $\$ 2,993.30$.

Although equipment and installation costs are higher initially, Wasse and Curtis determined that the pasteurization method seems to be more costeffective over the long term. However, consideration must be given to equipment currently available, space and the financial boundaries of the hospital before contemplating a change.

Whichever method of disinfection is decided upon, certain factors appear necessary as a minimum requirement for cleaning.

1 The cleaning method needs to consistently remove classical bacteria, primarily Pseudomonads, Serratio, Klebsiella, and Siaphylococcus aureus, since these are major organisms involved in cross-contamination.

2 There must be sufficient time for cleaning: as a minimum, thirty minutes per set of equipment.

3 There must be enough personnel and time to ensure that proper cleaning is done

4 Clean space is necessary to clean equipment and to store cleaned equipment. It is inefficient to take cleaned equipment and put it in a dirty place.

\section{Recommendations}

Either pasteurization or glutaraldehyde disinfection will rid tubings and circuits of classical bacteria provided the following recommendations are met.

1 Cleaning and disinfection of anaesthesia equipment should be delegated to conscientious well-trained individuals with a good understanding of contamination and the disinfection process.

2 Prior to disinfection, gross contamination should be physically removed.

3 All tubing and circuits should undergo the complete cycle as recommended by the manufacturer.

4 If using glutaraldehyde, thorough rinsing must be carried out to remove toxic chemical residuals.

5 A mechanism for drying should be provided since any dampness will encourage bacterial growth.

6 Clean, dry tubing circuits should be stored away from the wotk area in a clean dry covered place. 
The majority of surveyed hospitals subscribe to the recommended method of cleaning. However, 20 per cent of centres indicate other methods. Although change may be prohibitive because of costs and/or physical restrictions, nevertheless the recommended cleaning routine is basic to good infection control practices.

\section{Acknowledgements}

We thank Sheila Bannon for secretarial assistance, Dr. Charles Hope, Chief of Anaesthesia for the Victoria General Hospital, Danny Cashen, Chief Anaesthesia Technologist for the Victoria General Hospital and the Editorial Services of Dalhousie University.

\section{References}

1 Technical Standaras Commintee of the Association of Operating Room Nurses. Standards for cleaning and processing anaesthesia equipment. AORN J 1977; 25: 1268-74

2 du Moulin CG, Saubermann AJ. The anaesthesia machine and circle system are not likely to be sources of bacterial contamination. Anesthesiology 1977; 47; 353-8.

3 du Moulin GC, Hedley-Whyte J. Bacterial interactions between anesthesiologists, their patients, and equipment. Anesthesiology 1982; 57: 37-41.

4 Stark DCC, Green CA, Pask EA. Anaesthetic machines and cross-infection. Anaesthesia 1962; 17: 12-20.

5 Nielsen $H$, Jacobsen JB, Stokke DB, Brinklov MM. Christensen $K N$. Cross-infection from contaminated anaesthetic equipment. Anaesthesia 1980; 35: 703-8.

6 Cumpston P. Narasimhan S. Pseudomonas infection and the anaesthetist. Anaesth Intensive Care 1979: 7: 377-80

7 Dryden $G E$. Uncleaned anesthetic equipment. JAMA 1975; 233: 1297-8.

8 Dorsch J, Dorsch S. Understanding anesthesia equipment. Construction, Care and Complication. Baltimore: Willians and Wilkins, 1975; pp. 282-99.

9 Redman $L R$, Lockey $E$. Colonisation of the upper respiratory tract with gram-negative bacilli after operation, endotracheal intubation and prophylactic antibiotic therapy. Anaesthesia 1967; 22: 220-7.

10 Olds JW, Kisch AL, Eberle BJ, Wilson JN. $P$ seudomonas aeruginosa respiratory tract infection acquired from a contaminated anesthesia machine. Am Rev Respir Dis 1972; 105: 628-32

11 Deverill CEA, Dutt KK. Mcthods of decontamination of anaesthetic equipment: daily sessional exchange of circuits. $J$ Hosp Inf 1980; 1: 165-70.

12 Feeley TW, Hamilton WK, Xavier B, Moycrs J, Eger $E I H$. Sterilc anesthesia breathing circuits do not prevent postoperative pulmonary infection. Anesthesiology $1981 ; 54: 369-72$

13 Lumley J. Decontamination of anaesthetic equipment and ventilators. Br J Anaesth 1976; 48: 3-8.

14 Wasse $L$, Curtis $M$. Sterilization versus disinfection of anesthesia breathing circuits: safety and economic considerations. AANAJ 1982; 50: 16I-5.

15 Craig DB, Cowan SA, Forsyth W, Parker SE. Disinfection of anaesthesia equipment by a mechanized pasteurization method. Can Anaesth Soc J 1975; $22: 219-23$.

16 Gurevich I, Tafuro P, Ristuccia P, Herrmann J, Young $A R$, Cunha BA. Disinfection of respirator tubing: a comparison of chemical versus hot water machine-assisted processing. J Hosp Inf 1983; 4: 199-208.

\section{Résumé}

U'ne enquête pan-canadienne portant sur les techniques de nettoy'age des tubes et circuits d'anesthésie a élé effectuce. Trente-huit hopitaux universitaires de 250 lits et plus ont été consultés et 28 ( 74 pour cent) ont répondu.

La méthode la plus couramment employée (13/28) est le lavage à la gluteraldehyde suivi par la pasteurisation (9/28). Dans cet article on décrit ces deux mếthodes er on énumère les recommandations pour assurer une vérifable désinfection. 